(c) American Dairy Science Association, 2004.

\title{
Effects of Silymarin, a Natural Hepatoprotector, in Periparturient Dairy Cows
}

\author{
D. Tedesco, ${ }^{1}$ A. Tava,${ }^{2}$ S. Galletti, ${ }^{1}$ M. Tameni, ${ }^{1}$ G. Varisco, ${ }^{3}$ A. Costa, ${ }^{1}$ and S. Steidler ${ }^{1}$ \\ ${ }^{1}$ Department of Veterinary Science and Technology for Food Safety, \\ Faculty of Veterinary Medicine, \\ University of Milan, Via Celoria 10, 20133, Milan, Italy \\ ${ }^{2}$ Istituto Sperimentale per le Colture Foraggere, \\ Viale Piacenza, 26900 Lodi, Italy \\ ${ }^{3}$ Istituto Zooprofilattico Sperimentale della Lombardia e dell'Emilia Romagna "Bruno Ubertini", \\ Via A. Bianchi 9, 25124 Brescia, Italy
}

\section{ABSTRACT}

Silymarin, a natural acknowledged hepatoprotector used in humans to treat liver diseases, has been tested in dairy cows during peripartum, a period during which animals are subject to subclinical fatty liver. Ten grams of silymarin (76\% pure extract consisting in flavonolignans, taxifolin, and other trace compounds) per day, was administered as a water suspension by an oral drench to 15 cows from d 10 before expected calving to $15 \mathrm{~d}$ after calving. Milk production was measured, and colostrum, milk, and blood samples were analyzed during the experimental period. Treated animals showed the peak of milk production at $55 \pm 1.85 \mathrm{~d}$ after calving, 1 wk before the control group (62 $\pm 3.27 \mathrm{~d}$ ); the average peak production was $41.6 \pm 1.05 \mathrm{~kg}$ for the treated group vs. $39.1 \pm 1.44 \mathrm{~kg}$ for the control; the treated animals maintained a greater milk production than control cows throughout lactation $(9922.1 \pm 215.7$ vs. $9597.8 \pm 225.4$ $\mathrm{kg}$ ). Milk composition was unaffected by treatment. No silymarin residues were detected in colostrum and all milk samples. After calving, body condition score (BCS) decrease was greater for control compared with treated cows. Glucose, urea, triglycerides (TG), total cholesterol, $\beta$-hydroxibutyrate (BHBA), and $\gamma$-glutamyl transferase (GGT) in plasma were unaffected by treatment. Plasma nonesterified fatty acids (NEFA) on $d-7$ were higher in treated cows compared with the control group (741 vs. $181 \mu \mathrm{mol} / \mathrm{L}$ ). From this evidence, it is possible to conclude that silymarin beneficially affected lactation performances and body condition of treated animals. Blood and milk parameters do not indicate any adverse effects of feeding this natural compound.

(Key words: silymarin, peripartum, transition cow, milk yield)

Received June 1, 2003.

Accepted January 8, 2004.

Corresponding author: D. Tedesco; e-mail: doriana.tedesco@ unimi.it.
Abbreviation key: $\mathbf{A F B}_{\mathbf{1}}=$ aflatoxin $\mathrm{B}_{1}, \mathbf{A F M}_{\mathbf{1}}=$ aflatoxin $\mathbf{M}_{1}, \mathbf{G G T}=\gamma$-glutamyl transferase, $\mathbf{T G}=$ triglyceride.

\section{INTRODUCTION}

During the transition period in dairy cows, several physiological changes take place, and a number of studies have examined the biological mechanisms associated with this interval. Physiological changes persist during the transition period, defined as late gestation and the first $3 \mathrm{wk}$ of lactation, then stabilize at the end of this interval (Goff and Horst, 1997; Drackley, 1999).

Dairy cows experience moderate to severe fatty liver at calving (Gerloff et al., 1986; Tesfa et al., 1999; Jorritsma et al., 2001). Fatty liver occurs when the rate of fatty acid uptake and esterification exceeds the rate of fatty acid depletion either through oxidation or export as triglyceride (TG) within very low-density lipoproteins (Grummer, 1993).

Excessive TG accumulation into fat droplets within the hepatocytes impairs liver function. Fatty liver can cause cows to be more susceptible to other metabolic disorders, such as ketosis, which may seriously compromise health and productivity during lactation. Furthermore, periparturient cows are immunosuppressed with increased susceptibility to other pathologies (Mallard et al., 1998; Madsen et al., 2002). Fatty liver associated with altered humoral and cell-mediated immunity is one of the most important causes of increased susceptibility to infection such as mastitis and metritis, displaced abomasums, and decreased reproductive and productive performances (Gerloff et al., 1986; Goff and Horst 1997; Zerbe et al., 2000). According to Drackley et al. (2001), health problems during the transition period can result in potential losses in peak milk yield and lactation persistency.

It is possible that the severity of peripartum fatty liver could be reduced by using hepatoprotective agents that limit the extent of fat accumulation. Silymarin, a 
Table 1. Ingredient and nutrient composition of the prepartum and postpartum diets.

\begin{tabular}{lcr}
\hline Composition \% & & \\
Grass hay & 42.68 & - \\
Alfalfa hay & - & 56.00 \\
Corn silage & 48.78 & 13.70 \\
Corn grains & 2.44 & 10.30 \\
Soybean meal 44\% & 4.88 & 5.30 \\
Whole cottonseed & - & 2.00 \\
Sunflowers meal & - & 1.20 \\
Wheat milled & - & 1.00 \\
Molasses & 1.22 & 0.20 \\
Dicalcium phosphate & - & 0.50 \\
Sodium carbonate & - & 0.20 \\
Calcium carbonate & - & 0.30 \\
NaCl & - & 0.20 \\
Magnesium oxide & - & 1.00 \\
Megalac & & \\
Nutrient composition & 62.78 & 49.99 \\
DM, \% & 12.40 & 16.92 \\
CP, \% & 1.53 & 1.66 \\
NE ${ }_{\mathrm{L}}^{2}$, Mcal/kg & 55.15 & 34.54 \\
NDF, \% & 2.64 & 5.71 \\
Ether extract, \% & 0.68 & 0.86 \\
Ca, \% & 0.65 & 0.45 \\
P, \% & 7.42 & 7.98 \\
Ashes, \% & &
\end{tabular}

${ }^{1}$ Socoor S.r.l., Milan, Italy.

${ }^{2}$ NRC, 2001.

standardized extract from seeds of Silybum marianum L. (Gaertn.) (milk thistle), is used in humans for the treatment of liver diseases of different etiologies (Saller et al., 2001). Silymarin extract contains a mixture of flavonolignans and a residual fraction that has not yet been defined chemically in detail (Skottova et al., 2003). The interest in the potential benefits of silymarin originates in antiquity and is one of the first documented examples of plants used for maintenance of health and treatment of disease (Morazzoni and Bombardelli, 1995). It is reported that in presence of silymarin, hepatocyte protein biosynthesis and cell regeneration are accelerated in the damaged liver, leading to the restoration of its functions (Leng-Peschlow, 1996). This extract possesses antioxidant properties that prevent lipid peroxidation and membrane destruction in cells influencing cellular permeability (Muriel and Mourelle, 1990; Mira et al., 1994). Some authors reported that silymarin has hepatoprotective properties in experimental intoxication with Amanita phalloides (Kröncke et al., 1986) and aflatoxin $\mathrm{B}_{1}$ (Rastogi et al., 2000). An antitoxic effect is also suggested by a lower milk excretion of $\mathrm{AFM}_{1}$, an $\mathrm{AFB}_{1}$ metabolite, found in dairy cows receiving silymarin (Tedesco et al., 2003). Silybin, a major constituent of silymarin (Morazzoni and Bombardelli, 1995), stimulates phosphatidylcholine synthesis and increases the activity of cholinephosphate cytidyltransferase in rat liver both in normal condition and after intoxication by galactosamine (Schriewer and Wein- hold, 1973). Skottova et al. (2003) reported that the polyphenolic fraction of silymarin positively modifies lipoprotein profile in plasma and counteracts the development of fatty liver in rats. Furthermore silymarin significantly lowers the levels of serum $\gamma$-glutamyl transpeptidase, alanine transaminase, and aspartate transaminase in rats with ethanol-induced liver damage (Wang et al., 1996).

The objective of this experiment was to determine the effects of silymarin on lactation performance, animal health, milk composition, and blood metabolites in dairy cows in the transition phase between the dry and lactating periods.

\section{MATERIALS AND METHODS}

\section{Animals and Diet}

A commercial dairy herd with 700 lactating Italian Friesian dairy cows located in northern Italy was used. The herd was housed in a free-stall barn, fed on a TMR, and milked twice daily. At approximately $30 \mathrm{~d}$ from the expected date of parturition, 30 pregnant cows were selected according to their health condition, parity $(\geq 2)$, and previous milk production and with a BCS of approximately 3.7 according to Edmonson et al. (1989) and were assigned randomly to either the control or treated group.

From $d 10$ before the expected date of calving (assuming a gestation period of $280 \mathrm{~d}$ ) to d 15 after calving, 15 cows were treated with $10 \mathrm{~g}$ of silymarin $(76 \%$ pure extract consisting in flavonolignans, taxifolin, and other trace compounds) per day, provided by Indena S.p.A., Milan, Italy. To guarantee the dose intake, the extract was mixed with water into a ready-to-use suspension and was immediately administered by an oral drench. Due to inherent errors in predicting calving dates, the mean time of treatment prior to calving was $10 \mathrm{~d}$ (SD = 3.9 ) and ranged from 5 to $20 \mathrm{~d}$. Two cows were on treatments for less than $7 \mathrm{~d}$ prior to calving and only one for more than $14 \mathrm{~d}$.

Cows were fed a total mixed diet. Ingredient and nutrient composition of the diet is shown in Table 1 . All diets were fed ad libitum. Adaptation to the postpartum diet occurred over a 7-d period prior to the expected calving date, when cows received $30 \%$ of the postpartum diet.

Animals were monitored daily to evaluate general physical condition and health disorders by herd personnel or herd veterinarian. Pathological findings such as ketosis, mastitis, metritis, and dislocation of the abomasums were recorded. Additionally, urine collected weekly was tested for ketones (Ketur-test, Roche Diagnostics S.p.A., Milan, Italy). 
The animals used in this experiment were cared for in accordance with the guidelines established by the European Union and approved by the Italian Ministry of Health.

\section{BCS}

Body condition score was evaluated using a 5-point scale, at $15 \mathrm{~d}$ prepartum and successively at $7,21,30$ $\mathrm{d}$ postpartum. All BCS values were assigned by one individual scorer blinded as to treatment and previously recorded BCS.

\section{Milk Sampling and Analysis}

Daily milk production was electronically recorded for $305 \mathrm{~d}$. Colostrum and milk samples were drawn on d $0,7,21$, and 30 after parturition. Milk composition was evaluated on milk samples from d 7, 21, and 30, for fat, protein, and lactose content by infrared analyzer with a Milkoscan (Milk-o-Scan 605, Foss Electric, Hillerd, Denmark); urea was determined by a CL 10 (EUROCHEM, Foss Electric); SCC was determined by a Fossomatic (Fossomatic 360, Foss Electric).

Total silymarin residue in colostrum and in milk at $7 \mathrm{~d}$ of lactation was evaluated by HPLC.

\section{Determination of Total Silybin in Colostrum and Milk}

Total silybin was determined in colostrum and milk at $7 \mathrm{~d}$ of lactation after treatment of samples with $\beta$ glucuronidase/arylsulfatase according to Rickling et al. (1995) and modified as follows. A $10-\mathrm{mL}$ sample, to which $0.7 \mu \mathrm{g}$ of naringerin (IS, Sigma-Aldrich, Bologna, Italy) and $10 \mathrm{~mL}$ of $1 M$ acetate buffer $\mathrm{pH} 5.6$ were added, was treated with $300 \mu \mathrm{L}$ of $\beta$-glucuronidase/ arylsulfatase from Helix pomatia (Roche Diagnostics S.p.A., Milan, Italy) at $37^{\circ} \mathrm{C}$ for $16 \mathrm{~h}$ and $70 \mathrm{rpm}$ shaking. After adding $2 \mathrm{~mL}$ of $0.5 M$ borate buffer solution $\mathrm{pH}$ 8.5, silybin and the internal standard naringerin were extracted 3 times with $5 \mathrm{~mL}$ of diethyl ether by shaking the sample for about $20 \mathrm{~min}$. After centrifugation, the organic phases were transferred into a vial and evaporated at $40^{\circ} \mathrm{C}$ under a stream of nitrogen. The residue was redissolved in $100 \mu \mathrm{L}$ of ethanol, sonicated for a few minutes, filtered through a $0.2-\mu$ filter and used $(10 \mu \mathrm{L})$ for HPLC analyses.

The HPLC determination of silybin was performed on a Perkin Elmer chromatograph (Perkin Elmer Inc., Shelton, CT) equipped with LC 250 binary pump and a diode array 235 detector. Separations were performed on a RP18 column $(250 \times 4.6 \mathrm{~mm}$, X-Terra, 5 - $\mu \mathrm{m}$ particle size) using linear gradient from $100 \%$ of solvent $\mathrm{A}\left(\mathrm{H}_{2} \mathrm{O}\right.$ - $\left.10 \% \mathrm{CH}_{3} \mathrm{CN}-0.05 \% \mathrm{CH}_{3} \mathrm{COOH}\right)$ to $100 \%$ of solvent $\mathrm{B}$ $\left(\mathrm{CH}_{3} \mathrm{CN}-0.05 \% \mathrm{CH}_{3} \mathrm{COOH}\right)$ delivered at a flow rate of $1.0 \mathrm{~mL} / \mathrm{min}$ during $40 \mathrm{~min}$. Detection and calibration were performed at $290 \mathrm{~nm}$. Three independent runs were performed for each extract and silybin was identified by comparing retention time and UV spectra with those of previously purified standard. Standard silybin was purified from the flavonolignan mixture by semipreparative HPLC. The compound was identified by ${ }^{1} \mathrm{H}$ and ${ }^{13} \mathrm{C}$ nuclear magnetic resonance. Nuclear magnetic resonance data were in accordance with that reported in Kren et al. (1997).

For the calibration curve, a stock solution of silybin and the internal standard naringerin were prepared by dissolving each compound in ethanol. The working solutions in ethanol were obtained by diluting the stock solutions. For calibration, $10 \mathrm{~mL}$ of untreated milk was spiked with $700 \mathrm{ng}$ of naringerin and a variable concentration from 9.0 to $1700.0 \mathrm{ng}$ of silybin, corresponding to a final concentration of 0.9 to $170.0 \mathrm{ng} / \mathrm{mL}$ of silybin. Quantification was achieved by measuring the peak area of each compound and the internal standard. A standard curve of peak area ratio vs. the concentration in milk was plotted. The recovery of silybin $(78.2 \pm 2.7 \%)$ was assessed at 2 concentration levels by comparing the peak area after extraction with the peak area obtained from direct injection of equivalent quantities of the pure standards.

\section{Blood Sampling and Analysis}

Blood samples were collected in Li-heparin tubes (Venoject, Terumo Europe, Leuven, Belgium) from the jugular vein at $7 \mathrm{~d}$ before expected calving, at calving and at $\mathrm{d} 7$ after calving before feeding. Plasma was obtained by centrifugation at $3000 \mathrm{rpm}$ for $15 \mathrm{~m}$ at $10^{\circ} \mathrm{C}$ and frozen at $-20^{\circ} \mathrm{C}$ until analysis was performed. Plasma parameters evaluated were: total cholesterol (Alfa Wassermann esterase/oxidase method, Alfa Wassermann, Bologna, Italy), TG (Sigma diagnostic, procedure No 334-UV, Sigma-Aldrich), BHBA (Sigma diagnostic, procedure No 310-UV, Sigma-Aldrich), NEFA (Enzycolor, Boehringer-Mannheim, Monza, Italy), glucose (GOD-PAP method, Roche Diagnostics S.p.A., Milano, Italy), urea (Alfa Biotech, Pomezia, Rome, Italy), and GGT (IFCC method, Alfa Wassermann).

\section{Statistical Analysis}

The ANOVA of the previously described plasma constituents, individual milk traits, and BCS was performed using the MIXED procedure of SAS as repeated measures (SAS, 2001). The model contained the effects of treatment, time, and their interaction, random effect 


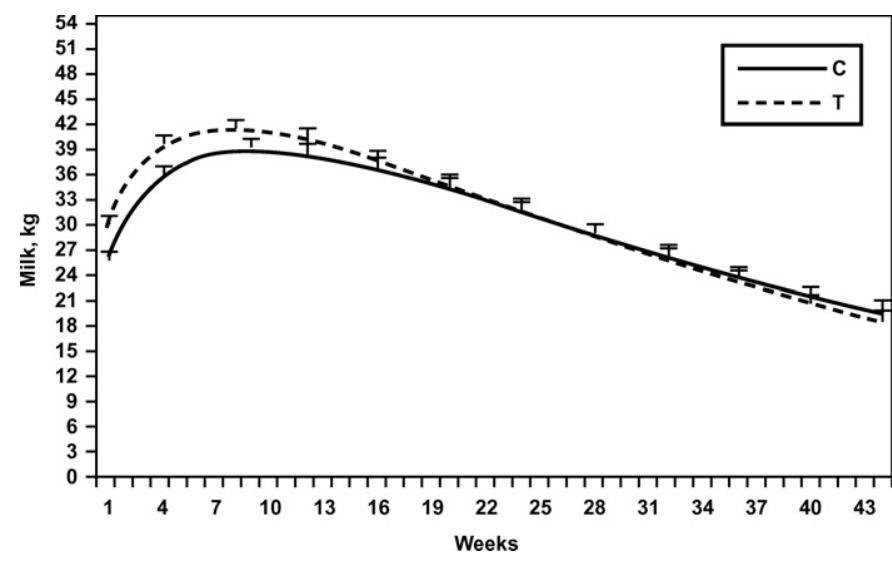

Figure 1. Milk yield lactation curves in control (solid line) and silymarin-treated cows (dashed line). Data represent least squared means \pm SEM.

of cows nested within treatment, and residual error. Somatic cell count was linearized by $\log _{10}$ SCC. Significance was declared at $P \leq 0.05$ and values are presented as least square means with pooled standard errors.

Milk yields recorded on $305 \mathrm{~d}$ of lactation were analyzed by nonlinear regression P-NLIN (Marquardt method) procedure of SAS (SAS, 2001) to determine lactation curves of each individual cow and parameters were calculated utilizing the Wood equation (Wood, 1967):

$$
\mathrm{Y}(\mathrm{n})=a \mathrm{n}^{b} \mathrm{e}^{(-c \mathrm{n})},
$$

where

$\mathrm{Y}=$ milk production,

$\mathrm{n}=$ time interval,

$a=\mathrm{a}$ scaling factor to represent yield at the beginning of lactation,

$b=$ slope of the ascending phase to the peak (index of the animal's capacity to use energy for production), and $\begin{aligned} c= & \text { slope of the descending phase to the peak } \\ & \text { (decay rate). }\end{aligned}$

The DIM at peak yield $\left(\mathrm{Y}_{\max }\right)$ was defined as $b / c$, and $\mathrm{Y}_{\max }$ was calculated as $a(b / c)^{b} e^{-b}$. The parameters thus obtained on the individual production, were submitted to ANOVA (Proc. GLM, SAS, 2001). Goodness of fit was assessed by comparing the predicted overall milk production to the actual milk yields (Proc. GLM, SAS, 2001).

\section{RESULTS}

\section{Health Status}

Until parturition, all cows remained apparently healthy. After parturition 1 case of mastitis and 2 incidences of dislocations of the abomasums were registered in the control group, while no cases were diagnosed in the treated group. No cows showed clinical signs of ketosis; nevertheless, one cow in control group resulted positive to Ketur-test. Fourteen cows developed metritis, respectively, 9 in control group and 5 in treated group.

\section{Milk Yield}

Figure 1 shows lactation curves of control and silymarin-treated groups. The 2 curves are characterized by a good coefficient of determination $\left(\mathrm{R}^{2}=0.96\right.$ for control and $R^{2}=0.98$ for silymarin-treated cows). The values of $a, b$, and $c$ are reported in Table 2. The shape of the curves, determined by Wood's equation (Wood, 1967) shows that the treated cows reached the lactation peak $1 \mathrm{wk}$ before the control $(\mathrm{C}=63 \pm 3.27 \mathrm{~d}$, $\mathrm{T}=$ $55 \pm 1.85 \mathrm{~d}$ [mean $\pm \mathrm{SEM}]$ ) and maintained a higher production throughout lactation. Average peak production was $41.6 \pm 1.05 \mathrm{~kg}$ for the treated group vs. 39.1 $\pm 1.44 \mathrm{~kg}$ for the control group $(P<0.05)$. A higher value of parameter $a$, which represents milk yield at the beginning of lactation, was recorded for treated

Table 2. Least square means and coefficient of determination of control and silymarin treated cows for lactation curve traits.

\begin{tabular}{|c|c|c|c|c|c|c|c|c|c|c|c|}
\hline & \multicolumn{7}{|c|}{ Lactation curve $^{1}$ traits } & \multicolumn{4}{|c|}{ Overall milk production } \\
\hline & \multicolumn{2}{|c|}{$a$} & \multicolumn{2}{|c|}{$b$} & \multicolumn{2}{|c|}{$c$} & \multirow[b]{2}{*}{$\mathrm{R}^{2}$} & \multicolumn{2}{|c|}{ Predicted } & \multicolumn{2}{|c|}{ Observed } \\
\hline & Mean & SEM & Mean & SEM & Mean & SEM & & Mean & SEM & Mean & SEM \\
\hline Cont & $26.77^{\mathrm{a}}$ & 1.44 & 0.31 & 0.04 & 0.034 & 0.02 & 0.96 & 9577.8 & 342.7 & 9597.8 & 225.4 \\
\hline Treated $^{2}$ & $30.85^{\mathrm{b}}$ & 1.32 & 0.28 & 0.05 & 0.035 & 0.57 & 0.98 & 9809.4 & 329.3 & 9922.1 & 215.7 \\
\hline
\end{tabular}

\footnotetext{
${ }^{\mathrm{a}, \mathrm{b}}$ Means with different superscripts differ significantly $(P<0.05)$.

1 " $a$ " is a scaling factor to represent yield at the beginning of lactation, and " $b$ " and " $c$ " are factors associated with the inclining and declining slope of the lactation curve.

${ }^{2} \mathrm{n}=15$.
} 
Table 3. Effect of silymarin treatment on lactation performances. ${ }^{1}$

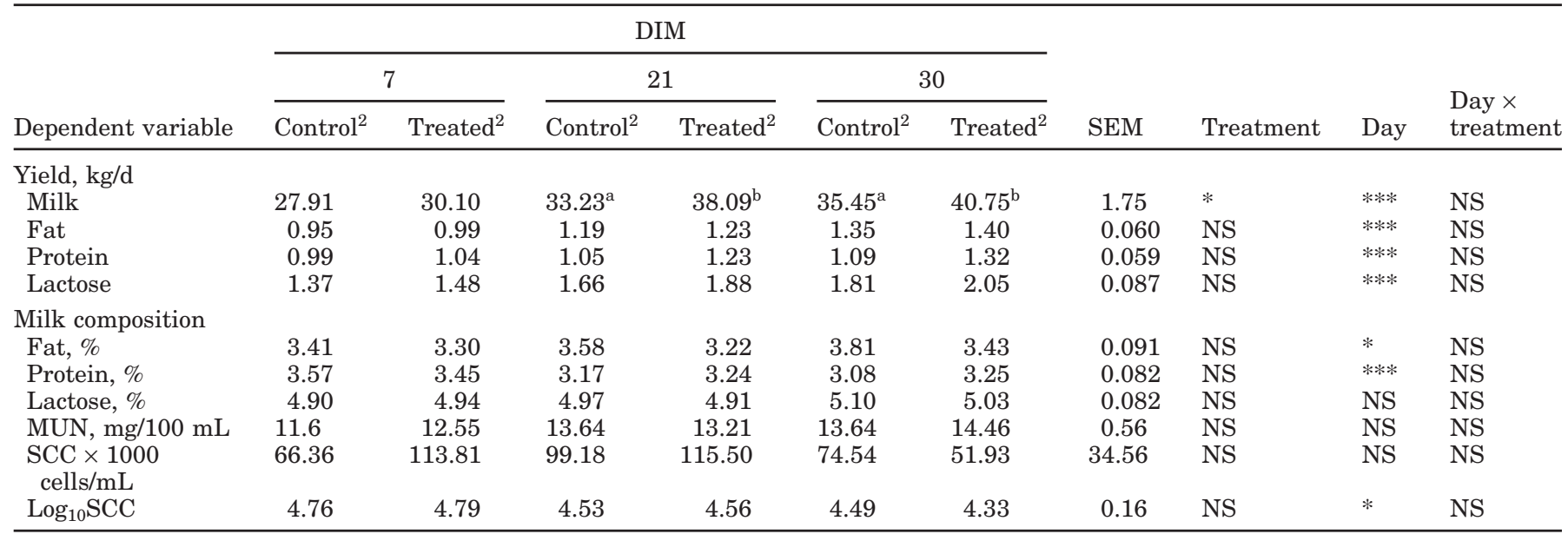

${ }^{\mathrm{a}, \mathrm{b}}$ Means with different superscripts differ significantly $(P<0.05)$.

${ }^{1} \mathrm{LS}$ means are presented with the pooled standard error of the mean (SEM).

${ }^{2} \mathrm{n}=15$.

$* P<0.05$.

$* * * P<0.001$.

cows (30.8 vs. $26.8 ; P<0.05)$. Consequently at a higher $a$ value, a slightly lower value of parameter $b$ was associated, which stands for the inclining slope of lactation curve. The declining slope of the lactation curve, decay rate $c$, slightly higher for treated animals (0.035 vs. 0.034 ), was not significantly different between treated and control animals during the rest of lactation. Milk yield was predicted with high accuracy by the model without significant difference with the actual milk yield (Table 2). Mean 305-d actual milk yield was 9922.1 \pm $215.7 \mathrm{~kg}$ for treated cows and $9597.8 \pm 225.4 \mathrm{~kg}$ for control cows.

As reported in Table 3, milk yield on 7 DIM averaged 27.9 and $30.1 \mathrm{~kg}$ for untreated and treated cows, respectively, and this difference was not statistically significant $(P>0.05)$. On 21 and 30 DIM, milk yield difference between untreated and treated animals was statistically significant $(P<0.05)$ : 33.2 vs. 38.1 and 35.4 vs. $40.7 \mathrm{~kg}$, respectively.

\section{BCS}

Body condition score values at the beginning of trial were included in the model as covariates. Since BCS was similar for all subjects of the 2 groups (at $15 \mathrm{~d}$ before expected calving BCS was $3.69 \pm 0.12$ and 3.73 \pm 0.14 in control and treated cows, respectively) it was dropped.

Body condition score was not affected by treatment, and no effect of interaction between day and treatment was observed $(P>0.05)$. A significant day effect was observed on BCS value $(P<0.001)$. The postpartum physiological body condition loss was evident in both groups, although the treated animals showed a lower body condition loss (Figure 2). BCS change from $15 \mathrm{~d}$ before calving and $30 \mathrm{~d}$ postpartum tended to be lower in treated animals $(P=0.055)$, the average BCS loss being $1.20 \pm 0.10$ for the control group and $0.93 \pm 0.10$ for silymarin-treated animals.

\section{Milk Constituents}

Values obtained from the milk constituent evaluation are reported in Table 3. No treatment effects on milk protein, lactose, MUN, and SCC were evident, and milk fat content tended to be lower in treated animals. With respect to the effect of the day of lactation, values of milk total protein $(P<0.001)$ and fat $(P<0.05)$ were significantly different according to DIM.

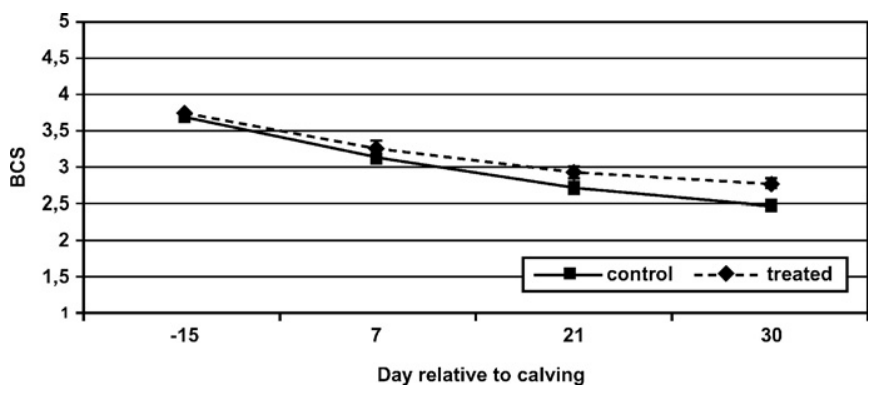

Figure 2. Body condition scores during prepartum and early postpartum periods in control (solid line) and silymarin treated cows (dashed line). Data represent least squared means \pm SEM. 


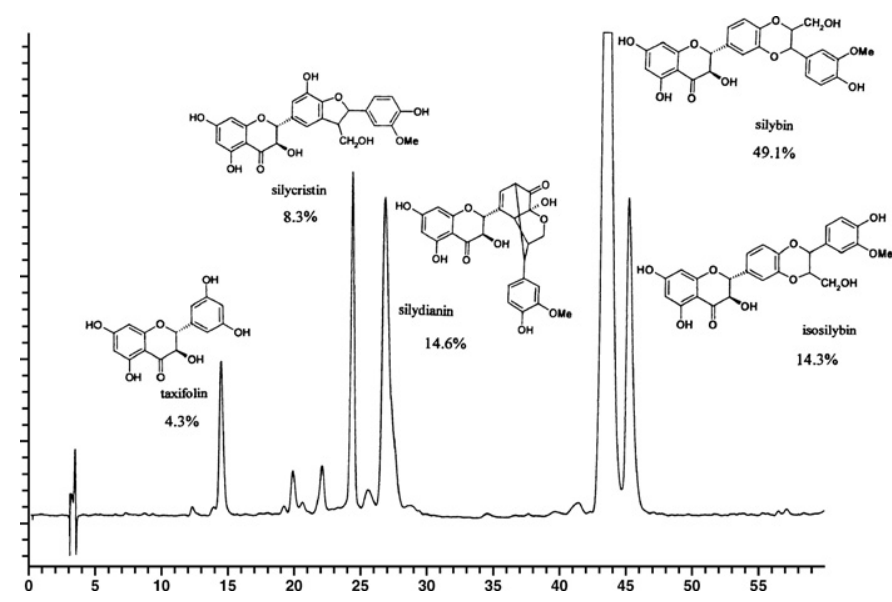

Figure 3. High performance liquid chromatogram of the silymarin mixture.

\section{Silybin Residue in Milk}

The silymarin mixture used in this trial was first analyzed by HPLC to quantify the single flavonolignans. The results, shown in Figure 3, allowed the quantification of all the constituents. This mixture consisted of $49.1 \%$ silybin, $14.3 \%$ isosilybin, $14.6 \%$ silydianin, $8.3 \%$ silycristin, and $4.3 \%$ taxifolin. The major bioactive compound, silybin, was purified and identified by nuclear magnetic resonance, and used as a standard reference. Because silybin is metabolized into its glucuronic and/or sulfonic derivatives as reported for humans in plasma (Rickling et al., 1995), the analyses were conducted after milk treatment with $\beta$-glucuronidase/arylsulfatase from Helix pomatia. In our trial, in which we used $10 \mathrm{~g}$ of silymarin/cow per day, no silybin residues were detected in milk samples, considering our detection limit determined as $10 \mathrm{ppb}$ (Figure 4).

\section{Plasma Constituents}

Values for glucose, urea, NEFA, TG, total cholesterol, BHBA, and GGT are given in Table 4. Treatment had a significant effect on NEFA concentrations at $-7 \mathrm{~d}$ from calving, averaging $181 \mu \mathrm{mol} / \mathrm{L}$ for control animals and $741 \mu \mathrm{mol} / \mathrm{L}$ for treated animals $(P<0.01)$. Day and day $\times$ treatment effects $(P<0.001)$ were also observed. At calving and at $d$, the concentration of NEFA declined in treated animals and was not different between the groups.

Treatment had no effect on glucose, urea, TG, cholesterol, BHBA, and GGT $(P>0.05)$. A day effect was recorded for glucose $(P<0.05)$, total cholesterol $(P<$ $0.001)$, and BHBA $(P<0.01)$. At calving, glucose concentration was higher than at $d-7$ and $d 7$; total cholesterol concentration declined at calving and then increased on
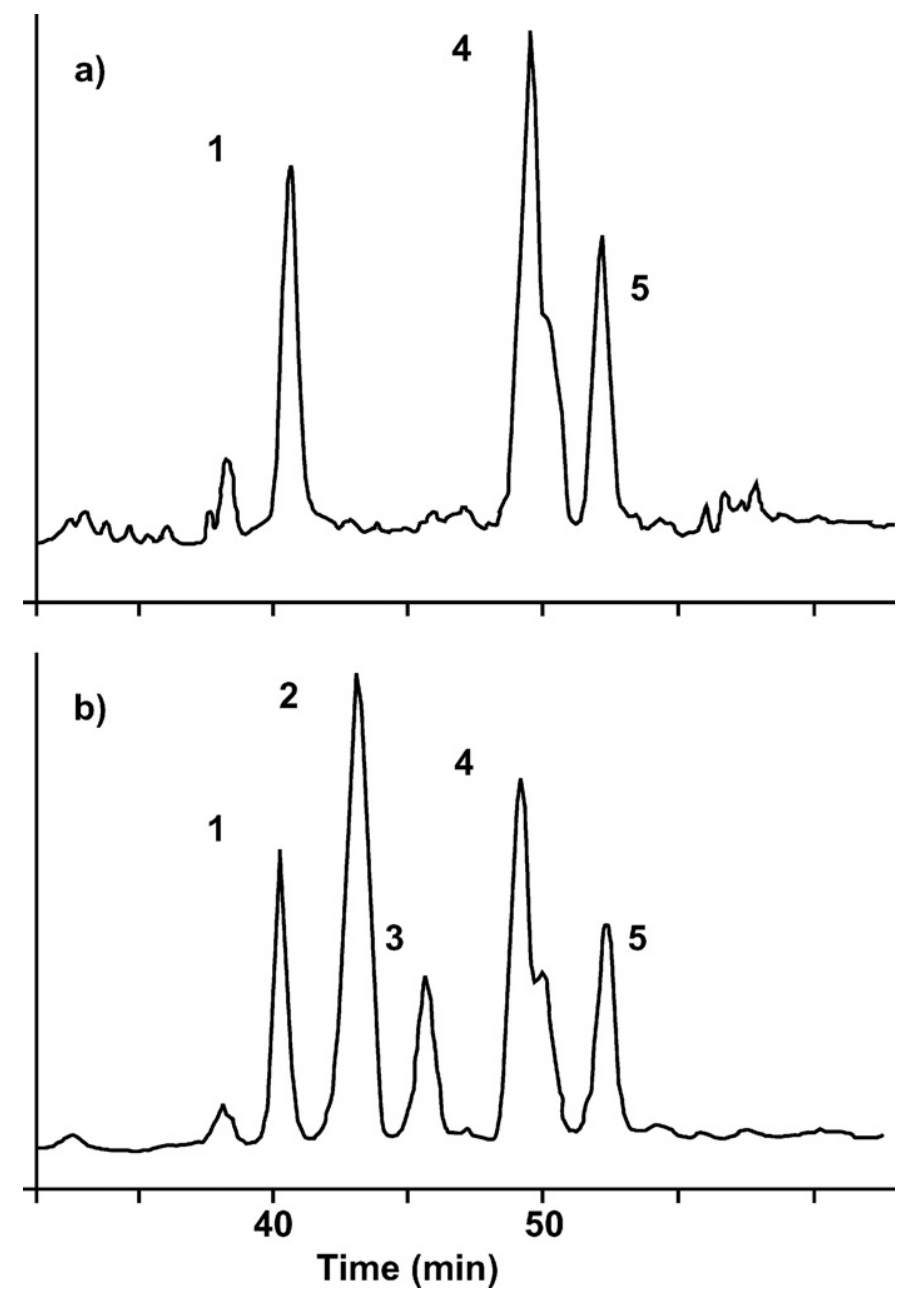

Figure 4. High performance liquid chromatogram of a) milk from cows receiving silymarin; b) milk to which silymarin was added in a dose of $120 \mathrm{ng} / \mathrm{mL}$. The peaks are identified as: 1) naringerin (internal standard); 2) silybin; 3) isosilybin; 4 and 5) unknown compounds.

d 7, more markedly in control animals (day $\times$ treatment effect; $P<0.05)$. Increasing plasma BHBA was recorded from calving to $7 \mathrm{~d}$.

No significant effects of day for urea, TG, and GGT $(P>0.05)$ were observed. There was a day $\times$ treatment interaction on GGT values $(P<0.05)$ : prepartum GGT concentration was lower in control animals and then increased at calving. An opposite trend was observed in treated animals.

\section{DISCUSSION}

Performance of dairy cows was observed for milk production throughout lactation (to 305 d) (Figure 1).

The silymarin-treated group showed a higher value of lactation curve trait $a$, indicating a higher yield at the beginning of lactation. For these animals, the milk 
Table 4. Effect of silymarin treatment on plasma constituents. ${ }^{1}$

\begin{tabular}{|c|c|c|c|c|c|c|c|c|c|c|}
\hline \multirow[b]{3}{*}{ Dependent variable } & \multicolumn{6}{|c|}{ Day relative to calving } & \multirow[b]{3}{*}{ SEM } & \multirow{2}{*}{\multicolumn{3}{|c|}{$P$}} \\
\hline & \multicolumn{2}{|c|}{-7} & \multicolumn{2}{|c|}{0} & \multicolumn{2}{|c|}{+7} & & & & \\
\hline & Control $^{2}$ & Treated $^{2}$ & Control $^{2}$ & Treated $^{2}$ & Control $^{2}$ & Treated $^{2}$ & & Treatment & Day & Day $\times$ treatment \\
\hline Glucose (mmol/L) & 3.27 & 3.45 & 4.20 & 3.87 & 3.37 & 3.07 & 0.30 & NS & $* *$ & NS \\
\hline Urea (mmol/L) & 4.78 & 4.81 & 5.27 & 4.47 & 4.75 & 4.34 & 0.411 & NS & NS & NS \\
\hline $\mathrm{NEFA}(\mu \mathrm{mol} / \mathrm{L})$ & $181^{\mathrm{A}}$ & $741^{\mathrm{B}}$ & 167 & 219 & 80 & 59 & 35 & $* * *$ & $* * *$ & $* * *$ \\
\hline Triglyceride $(\mathrm{mmol} / \mathrm{L})$ & 0.26 & 0.24 & 0.19 & 0.24 & 0.32 & 0.23 & 0.04 & NS & NS & NS \\
\hline $\mathrm{GGT}^{3}(\mathrm{U} / \mathrm{L})$ & 11.95 & 15.41 & 15.21 & 13.29 & 14.43 & 14.99 & 1.16 & NS & NS & * \\
\hline
\end{tabular}

$\mathrm{A}, \mathrm{B}$ Means with different superscripts differ significantly $(P<0.01)$.

${ }^{1} \mathrm{LS}$ means are presented with the pooled standard error of the mean (SEM).

${ }^{2} \mathrm{n}=15$.

${ }^{3} \mathrm{GGT}=\gamma$-Glutamyl transferase.

$* P<0.05$.

$* * P<0.01$.

$* * * P<0.001$

peak was reached $1 \mathrm{wk}$ before the control, leading to optimal milk production across the entire lactation, even though silymarin was administered for a short period of time. The treatment limited to the peripartum period is aimed to improve the metabolic transition, allowing the dairy cow to reach the peak in optimal conditions. The increase in peak milk production resulted in an improved total milk yield, as Lucy et al. (2001) suggested.

Since it is a new ingredient, silymarin should not be considered without data on the safety and quality of productions intended for human consumption. An important element in ensuring the safe use of silymarin in dairy cattle is the monitoring of its residues in milk. After $10 \mathrm{~g} / \mathrm{d}$ administration for more than a week, no silybin residue was detected (detection limit $=10 \mathrm{ppb}$ ). Despite the higher milk production in which we would expect a variation in the milk composition, no results showed this, although the treated animals showed a lower but not significant fat content (Table 3).

Body condition score was recorded and used as a parameter of animal performance. Condition score loss tended to be lower in treated cows, suggesting a minor lipomobilization with respect to untreated animals. Body condition loss may indicate an energetic disadvantage and has been associated to severe hepatic lipidosis (Gerloff et al., 1986).

Evidence of silymarin effects was also observed in plasma constituents. Silymarin-treated animals had a high plasma level of NEFA at $7 \mathrm{~d}$ prepartum $(741 \pm$ $37 \mu \mathrm{mol} / \mathrm{L}$ ) not associated with an increase of other parameters of lipid metabolism. Nevertheless, at calving, the NEFA level in treated animals diminished. Grummer (1993) stated that the increase in NEFA can be related to stress and decreased feed intake immedi- ately prior to calving. Other authors reported an increase of circulating NEFA 1 wk after parturition (Rukkwamsuk et al., 2000), associated with increased lipolysis (Van den Top et al., 1995). Vasquez-Anon et al. (1994) reported an exponential increase of the plasma NEFA concentration beginning at $\mathrm{d} 5$ prior to parturition and peaking $1 \mathrm{~d}$ after calving, associated with the hormone concentration changes that promote gluconeogenesis and mobilization of adipose tissue. Additionally, an increase in plasma lipolytic hormones may contribute to increasing plasma NEFA. The increase in NEFA with silymarin occurs predominantly during the prepartum period and appears to be a unique effect of silymarin because NEFA are not elevated postcalving despite continued silymarin supplementation. The decrease of NEFA in the plasma of treated cows was accompanied by a slight increase in BHBA. Different values of blood BHBA have been used to define subclinical ketosis: from $1200 \mu \mathrm{mol} / \mathrm{L}$ (Enjalbert et al., 2001) to $1400 \mu \mathrm{mol} / \mathrm{L}$ (Geishauser et al., 2000). The greater BHBA amount observed at $7 \mathrm{~d}$ after calving in both groups does not indicate a ketotic status (Table 4) and was not associated with a decrease in milk production, normally observed in ketotic cows. Furthermore, in our study glucose levels did not differ between groups, although an increase in milk production in treated animals was observed.

The severity of fatty liver can be evaluated using aspartate amino transferase and/or GGT values as markers of serious hepatic dysfunction or damage (Ohtsuka et al., 2001), while cows with mild fatty liver can have normal blood chemistry (Reid et al., 1983). The GGT levels observed both in control and treated animals do not indicate serious liver damage but cannot exclude the presence of mild hepatic lipidosis. Consider- 
ing all blood parameters investigated, the dairy cows in our trial can be considered as in a paraphysiological metabolic status associated with the transition period.

In lactating ketotic dairy cows, $S$. marianum seeds decreased blood, milk, and urine ketones and restored milk production (Vojtisek et al., 1991). In a comparative study using different planes of nutrition during the periparturient period, there was improvement in milk production and in reproductive parameters when 0.15 $\mathrm{kg} / \mathrm{d}$ of $S$. marianum seeds were fed to cows receiving a ketogenic diet (Vojtisek et al., 1993).

We administered silymarin for its hepatoprotective properties when dairy cows are at risk for fatty liver. In our approach, we attempted to verify the potential use of silymarin on periparturient dairy cows. The mechanisms underlying the positive effect of silymarin on production performances of dairy cows could not be elucidated in the present study on the basis of the investigated parameters. In spite of abundant literature on the pharmacology of silymarin, data on its influence on lipid metabolism in the liver are scanty. Much speculation can be made concerning the effects of this substance on humans. It has been shown that silymarin and its main bioactive compound, silybin, reduce the synthesis and turnover of phospholipids in the liver of rats and are able to reduce glycerol incorporation in lipids of isolated hepatocytes (Skottova and Kreeman, 1998). Furthermore, silymarin stimulates phosphatidylcholine synthesis (Schriewer and Weinhold, 1973). It has also been suggested that silymarin may diminish TG synthesis in the liver (Skottova and Kreeman, 1998) and activate fatty acid $\beta$-oxidation (Valenzuela and Garrido, 1994). Silybin in rats is able to partly antagonize the increase in total lipids and TG produced in the liver by carbon tetrachloride (Mourelle et al., 1989). The crucial protective mechanism is an inhibition of lipid peroxidation due to the free-radicalscavenging properties of silymarin (Dehmlow et al., 1996). Silymarin increases rRNA and cellular protein synthesis, which may be part of its action in liver (Sonnenbichler and Zetl, 1986). The action of silymarin on liver function, if also present in dairy cows, may promote the metabolic adaptation to early lactation. Minimizing the troubles associated to the transition period allows the cows to express their potential for peak milk production with repercussions across the entire lactation.

As reviewed previously (Tedesco, 2001), the use of natural bioactive compounds as additives in livestock nutrition instead of other chemical compounds, e.g., antibiotics, could be a new goal in livestock production as a natural consequence of the increased demand for safe products for human consumption. Silymarin is generally considered to be safe, and only in rare cases have adverse side effects been reported (Saller et al., 2001). An extensive search of published literature did not provide any evidence for toxicological properties of silymarin. The dose of silymarin used in the present experiment indicates a lack of transfer in milk, which would enable the use of silymarin as an adjuvant in periparturient dairy cows without raising concerns regarding the safety of the resulting milk and dairy products.

\section{CONCLUSIONS}

This study attempted to evaluate the potential use of silymarin, a safe natural product, to aid in the metabolic adaptation of dairy cows to the onset of lactation. Although the biochemical mechanisms that led to its effects have not been established, our results show a better BCS, a higher and earlier milk peak, and no negative conditions attributable to the use of this substance. Blood and milk parameters do not indicate any adverse effects of feeding cows this natural compound.

\section{ACKNOWLEDGMENTS}

This study was supported by the Italian Ministry of Education, University and Research (60\%).

\section{REFERENCES}

Dehmlow, C., N. Murawski, and H. De Groot. 1996. Scavenging of reactive oxygen species and inhibition of arachidonic acid metabolism by silibinin in human cells. Life Sci. 58:1591-1600.

Drackley, J. K., T. R. Overton, and G. Neil Douglas. 2001. Adaptations of glucose and long-chain fatty acid metabolism in liver of dairy cows during the periparturient period. J. Dairy Sci. 84(E. Sup$\mathrm{pl}): \mathrm{E} 100-\mathrm{E} 112$.

Drackley, J. K. 1999. Biology of dairy cows during the transition period: The final frontier? J. Dairy Sci. 82:2259-2273.

Edmonson, A. J., I. J. Lean, L. D. Weaver, T. Farver, and G. Webster. 1989. A body condition score scoring chart for Holstein dairy cows. J. Dairy Sci. 72:68-78.

Enjalbert, F., M. C. Nicot, C. Bayourthe, and R. Moncoulon. 2001. Ketone bodies in milk and blood of dairy cows: Relationship between concentrations and utilization for detection of subclinical ketosis. J. Dairy Sci. 84:583-589.

Geishauser, T., K. Leslie, J. Tenhagi, and A. Bashiri. 2000. Evaluation of eight cow-side ketone testes in milk for detection of subclinical ketosis in dairy cows. J. Dairy Sci. 83:296-299.

Gerloff, B. J., T. H. Herdt, and R. Emery. 1986. Relationship of hepatic lipidosis to health and performance in dairy cattle. JAVMA 188:845-850.

Goff, J. P., and R. L. Horst. 1997. Physiological changes at parturition and their relationship to metabolic disorders. J. Dairy Sci. 80:1260-1268.

Grummer, R. R. 1993. Etiology of lipid-related metabolic disorders in periparturient dairy cows. J. Dairy Sci. 76:3882-3896.

Jorritsma, R., H. Jorritsma, Y. H. Schukken, P. C. Bartlett, T. Wensing, and G. H. Wentink. 2001. Prevalence and indicators of post partum fatty infiltration of the liver in nine commercial dairy herds in The Netherlands. Livest. Prod. Sci. 68:53-60.

Kren, V., J. Kubisch, P. Sedmera, P. Halada, V. Prikrylova, A. Jegorov, L. Cvak, R. Gebhardt, J. Ulrichova, and V. Simanek. 1997. Glycosylation of silybin. J. Chem. Soc. Perkin Trans. 1:2467-2474.

Kröncke, K. D., G. Fricker, P. J. Meier, W. Gerok, T. Wieland, and G. Kurz. 1986. $\alpha$-Amanitin uptake into hepatocytes. Identification 
of hepatic membrane transport systems used by amatoxins. J. Biol. Chem. 261:12562-12567.

Leng-Peschlow, E. 1996. Properties and medical use of flavonolignans (silymarin) from Silybum marianum. Phytother. Res. 10:25-26.

Lucy, M. C., H. Jiang, and Y. Kobayashi. 2001. Changes in the somatotrophic axis associated with the initiation of lactation. J. Dairy Sci. 84(E. Suppl):E113-E119.

Madsen, S., P. S. D. Weber, and J. L. Burton. 2002. Altered expression of cellular genes in neutrophils of periparturient dairy cows. Vet. Immunol. Immunopathol. 86:159-175.

Mallard, B. A., J. C. Dekkers, M. J. Ireland, K. E. Leslie, S. Sharif, C. L. Vankampen, L. Wagter, and B. N. Wilkie. 1998. Alteration in immune responsiveness during the peripartum period and its ramification on dairy cow and calf health. J. Dairy Sci. 81:585595.

Mira, L., M. Silva, and C. F. Manso. 1994. Scavenging properties of reactive oxygen species by silibinin dihemisuccinate. Biochem. Pharmacol. 48:753-759.

Morazzoni, P., and E. Bombardelli. 1995. Silybum marianum (cardus marianus). Fitoterapia 66:3-42.

Mourelle, M., P. Muriel, L. Favari, and T. Franco. 1989. Prevention of $\mathrm{CCl}_{4}$-induced liver cirrhosis by silymarin. Fundam. Clin. Pharmacol. 3:183-191.

Muriel, P., and M. Mourelle. 1990. Prevention by silymarin of membrane alterations in acute $\mathrm{CCl}_{4}$ liver damage. J. Appl. Toxicol. 10:275-279.

Nutritional Research Council. 2001. Nutrient Requirements of Dairy Cattle. 7th rev. ed. National Academy of Sciences, Washington, DC.

Ohtsuka, H., M. Koiwa, A. Hatsugaya, K. Kudo, F. Hoshi, N. Itoh, H. Yokota, H. Okada, and S. Kawamura. 2001. Relationship between serum TNF activity and insulin resistance in dairy cows affected with naturally occurring fatty liver. J. Vet. Med. Sci. 63:10211025.

Rastogi, R., A. K. Srivastava, M. Srivastava, and A. K. Rastogi. 2000. Hepatocurative effect of picroliv and silymarin against aflatoxin $\mathrm{B}_{1}$ induced hepatotoxicity in rats. Planta Med. 66:709-713.

Reid, I. M., G. J. Rowlands, A. M. Dew, R. A. Collins, C. J. Roberts, and R. Manston. 1983. The relationship between post-parturient fatty liver and blood composition in dairy cows. J. Agric. Sci. 101:473-480.

Rickling, B., B. Hans, R. Kramarczyk, G. Krumbiegel, and R. Weyhenmeyer. 1995. Two high-performance liquid chromatographic assays for the determination of free and total silibinin diastereoisomers in plasma using column switching with electrochemical detection and reverse-phase chromatography with ultraviolet detection. J. Chromatogr. B 670:267-277.

Rukkwamsuk, T., M. J. H. Geelen, T. A. M. Kruip, and T. Wensig. 2000. Interrelation of fatty acid composition in adipose tissue, serum, and liver of dairy cows during the development of fatty liver postpartum. J. Dairy Sci. 83:52-59.

Saller, R., R. Meier, and R. Brignoli. 2001. The use of silymarin in the treatment of liver diseases. Drugs 61:2035-2063.
SAS User's Guide: Statistics, 2001. SAS Inst., Inc., Cary, NC.

Schriewer, H., and F. Weinhold. 1973. The influence of silybin from Silybum marianum (L.) gaertn. on in vitro phosphatidyl choline biosynthesis in rat livers. Arzneimittelforschung 29:791-792.

Skottova, N., and V. Kreeman. 1998. Silymarin as a potential hypocholesterolaemic drug. Physiol. Res. 47:1-7.

Skottova, N., R. Vecera, K. Urbanek, P. Vana, D. Walterova, and L. Cvak. 2003. Effects of polyphenolic fractions of silymarin on lipoprotein profile in rats fed cholesterol-rich diets. Pharmacol. Res. 47:17-26.

Sonnenbichler, J., and I. Zetl. 1986. Biochemical effects of the flavonolignane silibinin on RNA, protein and DNA sinthesis in rat livers. Pages 319-331 in Plant Flavonoids in Biology and Medicine: Biochemical, Pharmacological and Structure-Activity Relationship. V. Cody, B. Middleton, and J. B. Harborne, eds. Alan Liss Inc., New York, NY.

Tedesco, D. 2001. The potentiality of herbs and plant extracts as feed additive in livestock production. Zootec. Nutr. Anim. 3-4:111-133.

Tedesco, D., M. Tameni, S. Steidler, S. Galletti, and F. Di Pierro. 2003. Effect of silymarin and its phospholipid complex against AFM1 excretion in an organic dairy herd. Milchwissenschaft 58:416-419.

Tesfa, A. T., M. Tuori, L. Syriälä-Qvist, L. Pösö, H. Saloniemi, K. Heinonen, K. Kivilahti, T. Saukko, and L.-A. Lindber. 1999. The influence of dry period feeding on liver fat and postpartum performance of dairy cows. Anim. Feed Sci. Technol. 76:275-295.

Valenzuela, A., and A. Garrido. 1994. Biochemical bases of the pharmacological action of the flavonoid silymarin and of its structural isomer silibinin. Biol. Res. 27:105-112.

Van den Top, A. M., T. Wensing, M. J. H. Geelen, G. H. Wentink, A. T. Vant Klooster, and A. C. Beynen. 1995. Time trends of plasma lipids and enzymes synthesizing hepatic triacylglycerol during postpartum development of fatty liver in dairy cows. J. Dairy Sci. 78:2208-2220

Vasquez-Anon, M., S. Bertics, M. Luck, and R. R. Grummer. 1994. Peripartum liver triclyceride and plasma metabolites in dairy cows. J. Dairy Sci. 77:1521-1528.

Vojtisek, B., B. Hronova, J. Hamrik, and B. Jankova. 1991. Milk Thistle (Silybum marianum, L., Gaertn.) in the feed of ketotic cows. Vet. Med. Czech. 36:321-330.

Vojtisek, B., B. Hronova, J. Hamrik, and B. Jankova. 1993. Dietary silymarin in cows with various planes of nutrition in puerperal period. Zivoc. Vyr. 38:981-1001.

Wang, M., L. Grange, J. Tao, and E. Reyes. 1996. Hepatoprotective properties of Silybum marianum herbal preparation on ethanolinduced liver damage. Fitoterapia 67:166-171.

Wood, P. D. P. 1967. Algebraic model of the lactation curve in cattle. Nature 216:164-165.

Zerbe, H., N. Schneider, W. Leibold, T. Wensing, T. A. M. Kruip, and H. J. Schuberth. 2000. Altered Functional and immunophenotypical properties of neutrophilic granulocytes in postpartum cows associated with fatty liver. Theriogenology 54:771-786. 